\title{
Efektifitas Model Pembelajaran Blended Learning dalam Meningkatkan Kemampuan Berpikir Kritis dan Kemandirian Belajar Mahasiswa UPMI pada Mata Kuliah Statistik
}

\author{
Winanda Marito ${ }^{1}$, Nova Riani ${ }^{2}$ \\ 1, 2 Universitas Pembinaan Masyarakat Indonesia \\ J1. Teladan No.15, Teladan, Kota Medan, Sumatera Utara, 20214 \\ ndha62@gmail.com
}

\begin{abstract}
The purpose of this study was to see the effectiveness of the blended learning model, the differences in critical thinking skills and independent learning of students who were taught using the blended learning model and those taught using conventional learning. This study also aims to find out how to increase students' critical thinking skills and independent learning when taught using blended learning and conventional methods. This research method is quasi-experimental with Posttest Only Control Group Design with descriptive analysis used to achieve this goal. This research was conducted at UPMI Medan. The population of this study were all students of UPMI, while the sample was students of the Department of Management. This study found that the blended learning model was effectively used with a percentage of learning implementation worth $94.12 \%$ and student responses $89.50 \%$. then there are differences in critical thinking skills and independent learning between experimental and control class students, as evidenced by the sig. (2-tailed) 0.000 .05 between control and experimental groups. This study also found a greater improvement in critical thinking skills and independent learning of students taught using blended learning compared to conventional learning, as seen from the mean scores of 76.12 and 58.00 indicating an increase of $12.04 \%$.
\end{abstract}

Keywords: Blended Learning, conventional, critical thinking skills, learning independence.

\begin{abstract}
Abstrak
Tujuan penelitian ini adalah untuk melihat efektifitas model pembelajaran blanded learning, perbedaan kemampuan berpikir kritis dan kemandirian belajar mahasiswa yang diajar menggunakan model pembelajaran blended learning dengan yang diajarkan menggunakan pembelajaran konvensional. Penelitian ini juga bertujuan untuk mengetahui bagaimana peningkatan kemampuan berpikir kritis dan kemandirian belajar siswa ketika diajar menggunakan metode blended learning dan konvensional. Metode penelitian ini adalah quasieksperimental dengan Posstest Only Control Group Design dengan analisis deskriptif digunakan untuk mencapai tujuan ini. Penelitian ini dilakukan di UPMI Medan. Populasi penelitian ini adalah seluruh mahasiswa UPMI, sedangkan sampelnya adalah mahasiswa Jurusan Manajemen. Penelitian ini menemukan bahswa model pembelajaran blanded learning efektif digunakan dengan persentase keterlaksanaan pembelajaran senilai 94.12\% dan respon mahasiswa $89.50 \%$. kemudian terdapat perbedaan kemampuan berpikir kritis dan kemandirian belajar antara mahasiswa kelas eksperimen dan kontrol, yang dibuktikan dengan nilai sig. (2-tailed) 0,00 0,05 antara kelompok kontrol dan eksperimen. Studi ini juga menemukan peningkatan yang lebih besar dalam kemampuan berpikir kritis dan kemandirian belajar mahasiswa yang diajar menggunakan blended learning dibandingkan pembelajaran konvensional, seperti yang terlihat dari skor rata-rata 76.12 (kelompok eksperimen) dan 58.00 (kelompok kontrol), menunjukkan peningkatan 12,04\%.
\end{abstract}

Kata kunci: Blended Learning, konvensional, Kemampuan berpikir kritis, Kemandiran belajar

Copyright (c) 2021 Winanda Marito, Nova Riani

$\triangle$ Corresponding author: Winanda Marito

Email Address: ndha62@gmail.com (J1. Teladan No.15, Teladan, Kota Medan)

Received 16 November 2021, Accepted 08 December 2021, Published 05 January 2022

\section{PENDAHULUAN}

Di era global ini semakin banyak perkembangan teknologi yang sudah dimanfaatkan di berbagai bidang salah satunya adalah di dunia pendidikan. Karena teknologi tidak luput dari peran pendidikan yang harus ditekankan (Hendra, 2014). Teknologi yang bukan merupakan hal baru lagi dalam dunia pendidikan namun masih saja menjadi hal asing bagi dunia pendidikan di Indonesia, 
seperti yang terjadi pada saat kondisi pandemi Covid-19 ini, dunia pendidikan dari berbagai jenjang pendidikan 'dipaksa' bertransformasi untuk beradaptasi secara tiba-tiba drastis untuk melakukan pembelajaran dari rumah melalui media daring (online) (Atsani, Lalu Gede Muhammad Zainuddin, KH, 2020).

Dalam Permendikbud tahun 2020 pembelajaran adalah proses interaksi mahasiswa dengan Dosen dan sumber belajar pada suatu lingkungan belajar tertentu. Dengan kebijakan pemerintah saat ini untuk melaksanakan pembelajaran daring (online) maka dosen perlu berinovasi menggunakan sebuah strategi, metode, atau model pembelajaran yang efektif, interaktif, kolaboratif, dan berpusat pada mahasiswa yang dapat digunakan baik saat masa pandemi ini maupun setelahnya dengan tujuan dapat membangun kemampuan berpikir kritis mahasiswa.

Model pembelajaran Blended Learning mampu menciptakan proses pembelajaran berpusat pada mahasiswa. Dalam proses pelaksanaannya, dengan keterlibatan dan partisipasi dalam proses pembelajaran, Blended Learning dapat meningkatkan rasa tanggung jawab mahasiswa. Selain itu, adanya interaksi dalam model pembelajaran Blended Learning menciptakan suatu motif kepada mahasiswa untuk berkompetisi dalam belajar (Ningsih et al., 2017). Model pembelajaran Blended Learning memiliki komposisi $30 \%$ untuk tatap muka dan $70 \%$ dari penayangan materi secara online (Kenney \& Newcombe, 2011). Konsep awal model pembelajaran Blended Learning pertama kali dikembangkan pada 1960-an, sampai akhir 1990-an, dan istilah tersebut muncul dalam siaran pers pada tahun 1999, dimana Pusat Pembelajaran Interaktif yang mengubah namanya menjajdi EPIC Learning yang merupakan sebuah bisnis pendidikan di Atlanta yang mengoperasikan 220 kurus online menggunanakan metode campuran dalam kegiatan kursusnya.

Adapun tujuan dari pembelajaran Blended Learning adalah: 1) Membantu peserta didik untuk berkembang lebih baik di dalam proses belajar, sesuai dengan gaya belajar dan preferensi dalam belajar. 2) Menyediakan peluang yang praktis realistis bagi pendidik dan peserta didik untuk pembelajaran secara mandiri, bermanfaat, dan terus berkembang. 3) Peningkatan penjadwalan fleksibilitas bagi peserta didik, dengan menggabungkan aspek terbaik dari tatap muka dan instruksi online. 4) Kelas tatap muka dapat digunakan untuk melibatkan para peserta didik dalam pengalaman interaktif. Sedangkan porsi online memberikan peserta didik dengan konten multimedia yang kaya akan pengetahuan pada setiap saat, dan di mana saja selama peserta didik memiliki akses Internet. 5) Mengatasi masalah pembelajaran yang membutuhkan penyelesaian melalui penggunaan metode pembelajaran yang bervariasi (Husamah, 2014). Berikut tahapan dan sintaks model pembelajaran Blended Learning (Lumbantoruan \& Hidayat, 2013). 


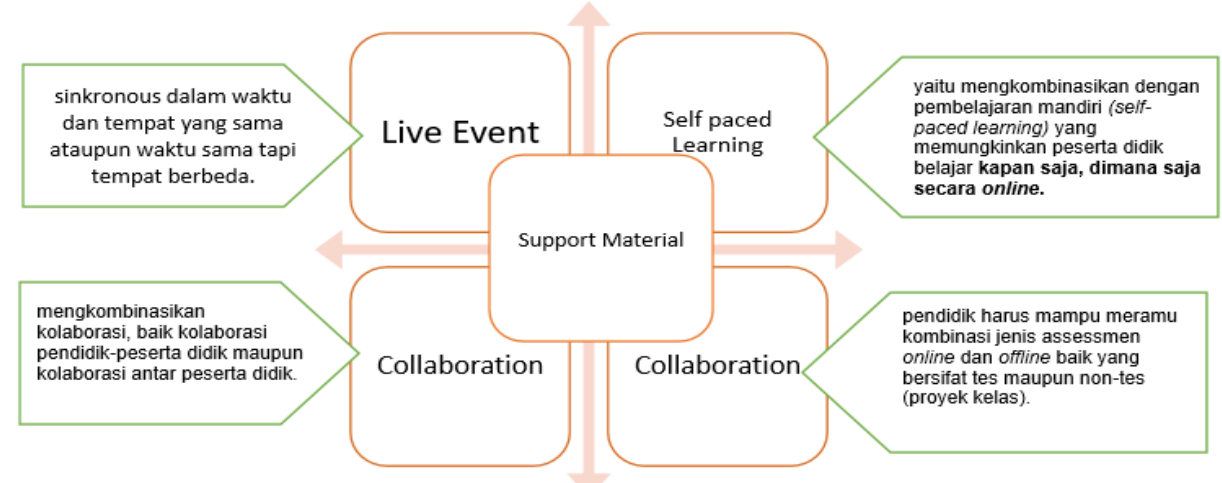

Gambar 1. Tahapan Pembelajaran Blended Learning

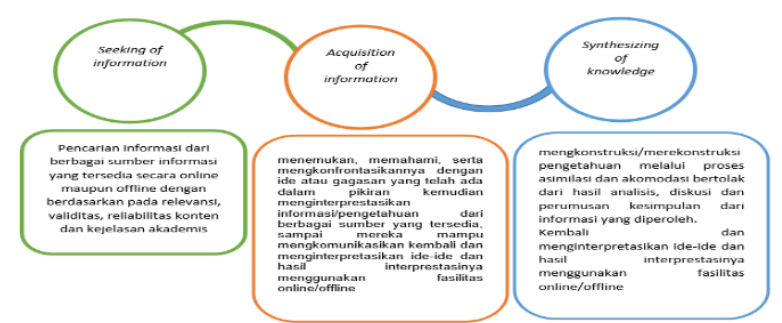

Gambar 2. Sintaks Pembelajaran Blended Learnig

Kemandirian belajar didefinisikan sebagai proses belajar yang terjadi karena pengaruh dari pemikiran, perasaan, strategi, dan perilaku sendiri yang berorientasi pada pencapaian tujuan keberhasilan mahasiswa dalam belajar matematika ditentukan oleh kemandirian belajar dari masingmasing individu (Sumarmo, 2002). Guru/dosen sebaiknya melaksanakan proses pembelajaran yang dapat memfasilitasi muridnya agar memiliki kemandirian belajar. Ini berarti bahwa dosen hendaknya mendesain suatu pembelajaran yang dapat membuat mahasiswa menjadi mandiri dalam belajar (Zumbrunn, 2011). Beberapa indikator untuk mengukur kemandirian belajar peserta didik yaitu: (1) inisiatif belajar; (2) mendiagnosa kebutuhan belajar; (3) menetapkan target atau tujuan belajar; (4) memonitor, mengatur dan mengontrol; (5) memandang kesulitan sebagai tantangan; (6) memanfaatkan dan mencari sumber yang relevan; (7) memilih dan menerapkan strategi belajar; (8) mengevaluasi proses dan hasil belajar; (9) self-efficacy (konsep diri). Sedangkan faktor-faktor yang mempengaruhi kemandirian belajar meliputi : pengetahuan (knowledge), motivasi (motivation) dan disiplin pribadi (selfdiscipline) (Wahyuni, 2013).

Berpikir kritis sebagai berpikir reflektif yang beralasan dan difokuskan pada penetapan apa yang dipercayai atau yang dilakukan.(Hendriana, H., \& Soemarmo, 2014). Terdapat dua belas indikator berpikir kritis yang dikelompokkan dalam lima kemampuan berpikir, yaitu: Memberikan penjelasan sederhana (elementary clarification); (2) Membangun keterampilan dasar (basic support); (3) Membuat kesimpulan (inferring); (4) Membuat penjelasan lebih lanjut (advanced clarification); (5) Mengatur Strategi dan Taktik (Strategis and Tactics) (Prabawati, 2011). 
Statistika merupakan ilmu pengetahuan yang berhubungan dengan cara-cara pengumpulan fakta, pengolahan, serta penganalisanya, pengambilan kesimpulan, penyajian, dan publikasi dari datadata yang berbentuk angka. Riset dan statistika merupakan dua hal yang tidak dapat dipisah, oleh karena itu di perguruan tinggi statistika menjadi mata kuliah yang harus diambil mahasiswa, karena mata kuliah ini penting dalam penyusunan tugas akhir mahasiswa yang berbentuk sebuah riset (penelitian) (Mahmudah, 2020).

Namun dalam pelaksanaannya banyak mahasiswa yang kesulitan dalam memahami konsep statistik tersebut, sehingga tidak sedikit mahasiswa mengalami kecemasan hingga rasa pesimis dalam belajar statistika (Ningsih et al., 2017). Hal tersebut juga terjadi dalam pelaksaan perkuliahan mata kuliah statistika di Program Studi Manajemen UPMI Medan. Berdasarkan nilai Ujian Tengah Semester (UTS) semester 3 kelas A dan B nilai rata-rata yang didapatkan mahasiswa sebesar 59.65. Dimana ketutasan minimal nilai mahasiswa yaitu $\geq 70$. Artinya mahasiswa belum mampu mecapai lulusan pembelajaran dalam mata kuliah statistika, selain itu interaksi dalam pembelajaran masih bersifat searah yaitu berpusat pada dosen. Mahasiswa belum mandiri dalam belajar hanya, menunggu instruksi dari dosen, belum berinisiatif mencari sumber belajar lain. Selain itu, berdasarkan hasil observasi ketika diskusi di dalam kelas mahasiswa belum mampu berkolaboratif antar sesama mahasiswa, tidak semua berpeeran aktif untuk menyelesaikan permasalahan yang diberikan dosen. Selain itu dalam kemampuan berpikir kritis mahasiswa juga belum mampu membangun keterampilan dasar (basic support), membuat kesimpulan (inferring), membuat penjelasan lebih lanjut (advanced clarification), mengatur strategi dan taktik (Strategis and Tactics) dalam penyelesaian masalah yang diberikan terkait statistik.

Adapun tujuan penelitian ini adalah untuk untuk mengetahui bahwa model pembelajaran Blended Learning efektif digunakan sebagai salah satu alernatif dalam kegiatan pembelajaran dengan mengetahui perbedaan peningkatan kemampuan berpikir kritis dan kemandirian belajar antara mahasiswa yang diajar menggunakan model pembelajaran Blended Learning dengan mahasiswa yang diajar menggunakan pembelajaran konvensional, dimana peningkatan kemampuan berpikir kritis dan kemandirian belajar kelas eksperimen lebih baik daripada kelas kontrol.

\section{METODE}

Penelitian ini menggunakan pendekatan quasi eksperimen dengan rancangan Penelitian Posstest Only Control Group Design dengan analisis deskriptif. Dengan menggunakan pendekatan tersebut indikator - indikator variabel dalam penelitian ini dapat diukur dengan jelas dan dianalisis secara deskriptif untuk memperkuat analisa dalam membuat kesimpulan. Data yang digunakan dalam penelitian ini merupakan data primer dari responden yang menjadi sampel. Populasi dalam penelitan ini adalah seluruh mahasiswa UPMI. Sampel penelitian ini mahasiswa UPMI Medan Program Studi Manajemen yang terdiri dari 2 kelas yaitu kelas A dan B. Cara pengambilan sampel dengan 
menggunakan Non probabillity sampling. Penarikan sampel dilakukan berdasarkan sampling purposive. Perhitungan sampel menggunakan rumus slovin.

Pengumpulan data dilakukan menggunakan instrumen wawancara, lembar pengamatan keterlaksanaan pembelajaran, kuisioner, dokumentasi dan tes. Proses wawancara dilakukan dengan dosen statistik guna memperoleh informasi yang berterkaitan dengan permasalahan yang dihadapi mahasiswa selama pembelajaran jarak jauh. Lembar observasi keterlaksanaan pembelajaran digunakan sebagai pedoman penilaian untuk mengukur kesesuaian antara RPS dan proses pembelajaran yang berlangsung. Kuisioner digunakan untuk melihat tingkat kemandirian belajar juga respon mahasiswa. Dan instrument tes yang berupa postes digunakan dalam mengukur kemampuan berpikir kritis mahasiswa. Sebelum kuisioner disebarkan pada mahasiswa maka dilakukan pengujian validitas dan reliabilitas instrument terlebih dahulu, dan untuk posest dilakukan pengujian daya beda sekaligus tingkat kesukaran soal. Analisis data pengukuran keterlaksanaan pembelajaran dihitung menggunakan rumus sebagai berikut :

$$
\text { Persentase Keterlaksanaan Pembelajaran }=\frac{\text { Jumlahitem terlaksana }}{\text { Jumlahitem keseluruhan }} \times 100 \%
$$

Selanjutnya dihitung rata-rata persentase keterlaksanaan setiap pertemuan dengan rumus berikut:

$$
X p_{k}=\frac{A P_{k}}{n}
$$

Rata - rata persentase keterlaksanaan tersebut digunakan untuk mengkategorikan keberhasilan pembelajaran yang telah dilaksanakan. Berikut ini kriteria rata - rata presentas keterlaksanaan pembelajaran:

Tabel 1. Kriteria Keterlaksanaan Pembelajaran

\begin{tabular}{|c|c|}
\hline Intreval & Kriteria \\
\hline $75<\mathrm{Xpk} \leq 100$ & Baik \\
\hline $50<\mathrm{Xpk} \leq 75$ & Cukup Baik \\
\hline $25<\mathrm{Xpk} \leq 50$ & Kurang Baik \\
\hline $0<\mathrm{Xpk} \leq 25$ & Buruk \\
\hline
\end{tabular}

Selanjutnya, analisis data respon peserta didik terhadap pembelajaran Blended Learning dihitung menggunakan rumus sebagai berikut:

$$
\text { Respon }(\%)=\frac{\text { Jumlah Skor Total }}{\text { Jumlah Skor Ideal }} \times 100 \%
$$

Setelah diperoleh persentase respon peserta didik, selanjutnya dapat dikategorikan rata-rata respon peserta didik tersebut sesuai tabel dibawah ini: 
Tabel 2. Kriteria Respon Peserta Didik

\begin{tabular}{|l|l|}
\hline \multicolumn{1}{|c|}{ Rentang Persentase } & \multicolumn{1}{c|}{ Kriteria } \\
\hline $0 \%-20 \%$ & Sangat Kurang \\
\hline $21 \%-40 \%$ & Kurang \\
\hline $41 \%-60 \%$ & Cukup \\
\hline $61 \%-80 \%$ & Baik \\
\hline $81 \%-100 \%$ & Sangat Baik \\
\hline
\end{tabular}

(Riduwan, 2011)

Dalam riset ini, pengujian hipotesis menggunakn Uji Independent Sample t Test. Pengujian hipotesis dilakukan guna mengetahui perbedaan rerata tingkat berpikir kritis dan kemandirian belajar mahasiswa antara kelas eksperimen dan kelas kontrol. Sebelum uji t maka dilakukan pengujian prasyarat terlebih dulu pada data yang diperoleh yaitu uji normalitas dan uji homogenitas. Pengujian ini berguna untuk mengetahui data yang diperoleh terdistribusi normal atau tidak, homogen atau tidak. Kedua uji tersebut merupakan syarat mutlak yang harus dipenuhi sebelum melakukan uji T Test. Perhitungan analasisis data dalam penelitian ini menggunakan SPSS 25.

\section{HASIL DAN DISKUSI}

Penelitian ini dilakukan dengan memberikan pretes disertai angket kemandirian belajar pada mahasiswa program studi manajemen yang berjumlah 50 orang dimana masing - masing kelas terdiri dari 25 orang pada kelas Manajemen A dan 25 orang pada kelas Manajemen B. Pemberian pretes sebagai tahap awal adalah untuk mengetaui tingkat pemahaman mahasiswa tentang dasar materi kuliah statistik serta mengetahui tingkat kemandirian belajar mahasiswa sebelum diterapkan model pembelajaran Blended Learning. Kemandirian belajar mahasiswa dapat dilihat dan diukur dari beberapa aspek yaitu aspek inisiatif, percaya diri, dan motivasi.

Tahap selanjutnya adalah melaksanakan kegiatan pembelajaran di kelas eksperimen menggunakan model Blended Learning dan kelas kontrol menggunakan pembelajaran konvensional. Tujuannya adalah untuk melihat perbedaan peningkatan kemampuan berpikir kritis mahasiswa dan kemandirian belajar mahasiswa antara kelas eksperimen dengan kelas kontrol.

Proses pembelajaran mata kuliah stiatistik menggunakan model pembelajaran Blended Learning dilakukan di kelas Manajemen A sebagai kelas ekperimen dan kelas manajemen B menggunkan pembelajaran konvensioanl sebagai kelas kontrol. Pelaksanaan pembelajaran pada masing-masing kelas adalah 4 kali pertemuan. Untuk mengetahui tingkat kemampuan berpikir kritis dan kemandirian belajar mahasiswa maka pada tahap akhir penelitian diberikan postes serta angket kemandirian belajar kepada responden. Kemudian nilai postes dan angket disertai angket yang diberikan sebelum menerapkan pembelajaran akan dibandingkan dengan nilai postes serta angket kemandirian belajar pada tahap akhir untuk mengetahui hasil yang diharapkan.

Keterlaksanaan suatu proses pembelajaran dapat dilihat berdasarkan lembar observasi keterlaksanaan pembelajaran yang telah diamati oleh observer. Observer dalam penelitian ini yaitu 
salah satu dosen Matematika di UPMI Medan. Pengamatan keterlaksanaan pembelajaran dilakukan pada kelas eksperimen yakni kelas Manajemen A. yang berjumlah 25 orang sedangkan kelas Manajemen B sebagai kelas kontrol berjumlah 25 orang.

Dalam lembar observasi keterlaksanaan pembelajaran terdapat tiga aspek utama yang diamati oleh observer yaitu meliputi aspek pembelajaran asinkron mandiri, sinkronus virtual dan asinkron kolaboratif. Pembelajaran sinkronus virtual mencakup kegiatan pendahuluan, kegiatan inti dan penutup. Proses pembelajaran dilaksanakan selama 4 kali pertemuan. Berikut persentase keterlaksanaan pembelajaran model Blended Learning pada kelas eksperimen.

Tabel 3. Keterlaksanaan Pembelajaran Blended Learning

\begin{tabular}{|c|c|c|c|}
\hline Pertemuan 1 & Pertemuan 2 & Pertemuan 3 & Pertemuan 4 \\
\hline $100 \%$ & $100 \%$ & $86,50 \%$ & $90 \%$ \\
\hline \multicolumn{3}{|c|}{ Rata - rata $=94.12 \%$} \\
\hline
\end{tabular}

Rata - rata persentase keterlaksanaan pembelajaran Blended Learning adalah $94.12 \%$ yang dapat dikategorikan baik. Hal tersebut menunjukkan bahwa pelaksanaan proses pembelajaran dengan model pembelajaran Blended Learning sudah terlaksana dan sesuai dengan RPS / SAP yang disusun dan keterlaksanaan pembelajaran dikategorikan terlaksana dengan baik. Selanjutnya untuk melihat efektifitas model pembelajaran Blended Learning salah satunya dapat dilihat berdasarkan respon mahasiswa setelah memperoleh pembelajaran. Berikut persentase dari respon mahasiswa yang terdapat dalam empat indikator.

Tabel 4. Persentase Respon Mahasiswa

\begin{tabular}{|l|l|c|}
\hline No & \multicolumn{1}{|c|}{ Indikator } & Rata-rata frekuensi \\
\hline 1 & Ketertarikan atau Atensi & $89.33 \%$ \\
\hline 2 & Relevansi & $88.00 \%$ \\
\hline 3 & Confidence & $94.00 \%$ \\
\hline 4 & Literasi terhadap ICT & $86.67 \%$ \\
\hline \multicolumn{2}{r}{ Total } & $89.50 \%$ \\
\hline
\end{tabular}

Dalam penelitian ini respon yang diperoleh hanya berasal dari kelas eksperimen yang mendapatkan perlakuan. Pada hasil yang diperoleh, diketahui respon mahasiswa terhadap pembelajaran Blended Learning dikategorikan sangat baik yaitu dengan persentase $89.50 \%$. Sehingga dapat disimpulkan bahwa penerapan model pembelajaran Blended Learning pada mata kuliah statistik yang apabila ditinjau dari respon mahasiswa dikatakan efektif untuk diterapakan di masa pandemi Covid-19 dan new normal. Untuk mengetahui perbedaan kemapuan berpikir kritis dan kemandirian belajar mahasiswa pada kelas eksperimen dan kontrol maka dilakuakan uji t. berikut hasil perhitungan uji t. 
Tabel 5. Hasil Uji Paired Sample t tests Statistics Kemandirian Belajar

\begin{tabular}{|l|l|r|r|r|r|}
\hline \multicolumn{7}{|c|}{ Paired Samples Statistics } \\
\hline \multicolumn{2}{|c|}{} & \multicolumn{1}{c|}{ Mean } & N & \multicolumn{1}{c|}{ Std. Deviation } & Std. Error Mean \\
\hline \multirow{2}{*}{ Pair 1 } & EKSPERIMEN & 115.3600 & 25 & 2.48126 & .49625 \\
\cline { 2 - 6 } & KONTROL & 110.8800 & 25 & 4.16653 & .83331 \\
\hline
\end{tabular}

Table 6. Hasil Uji Paired Sample t tests Kemandirian Belajar

\begin{tabular}{|c|c|c|c|c|c|c|c|c|c|}
\hline \multicolumn{10}{|c|}{ Paired Samples Test } \\
\hline & & \multicolumn{5}{|c|}{ Paired Differences } & \multirow[b]{3}{*}{$\mathrm{t}$} & \multirow[b]{3}{*}{ df } & \multirow{3}{*}{$\begin{array}{l}\text { Sig. (2- } \\
\text { tailed) }\end{array}$} \\
\hline & & \multirow[b]{2}{*}{ Mean } & \multirow{2}{*}{$\begin{array}{c}\text { Std. } \\
\text { Deviation }\end{array}$} & \multirow{2}{*}{$\begin{array}{l}\text { Std. Error } \\
\text { Mean }\end{array}$} & \multicolumn{2}{|c|}{$\begin{array}{l}95 \% \text { Confidence } \\
\text { Interval of the } \\
\text { Difference }\end{array}$} & & & \\
\hline & & & & & Lower & Upper & & & \\
\hline $\begin{array}{l}\text { Pair } \\
1\end{array}$ & \begin{tabular}{|l|} 
EKSPERIMEN - \\
KONTROL
\end{tabular} & 4.48000 & 4.09390 & .81878 & 2.79012 & 6.16988 & 5.472 & 24 & .000 \\
\hline
\end{tabular}

Table 7. Hasil Uji Paired Sample t Test statitics Berpikir Kritis

\begin{tabular}{|l|l|l|r|r|r|}
\hline \multicolumn{7}{|c|}{ Paired Samples Statistics } \\
\hline \multirow{2}{|c|}{ Pair 1 } & Mean & N & \multicolumn{1}{c|}{ Std. Deviation } & Std. Error Mean \\
\cline { 2 - 6 } & EKSPERIMEN & 76.1250 & 25 & 7.37747 & 1.47549 \\
\cline { 2 - 6 } & KONTROL & 58.5000 & 25 & 11.35799 & 2.27160 \\
\hline
\end{tabular}

Table 8. Hasil Uji Paired Sample t test Berpikir Kritis

\begin{tabular}{|c|c|c|c|c|c|c|c|c|c|}
\hline \multicolumn{10}{|c|}{ Paired Samples Test } \\
\hline & & \multicolumn{5}{|c|}{ Paired Differences } & \multirow[b]{3}{*}{$\mathrm{t}$} & \multirow[b]{3}{*}{ df } & \multirow{3}{*}{$\begin{array}{l}\text { Sig. }(2- \\
\text { tailed) }\end{array}$} \\
\hline & & \multirow[b]{2}{*}{ Mean } & \multirow{2}{*}{\begin{tabular}{|c|} 
Std. \\
Deviatio \\
$\mathrm{n}$ \\
\end{tabular}} & \multirow{2}{*}{$\begin{array}{c}\text { Std. Error } \\
\text { Mean } \\
\end{array}$} & \multicolumn{2}{|c|}{$\begin{array}{c}95 \% \text { Confidence } \\
\text { Interval of the } \\
\text { Difference }\end{array}$} & & & \\
\hline & & & & & Lower & Upper & & & \\
\hline $\begin{array}{l}\text { Pair } \\
1\end{array}$ & $\begin{array}{l}\text { EKSPERIMEN } \\
\text { - KONTROL }\end{array}$ & 17.62500 & 6.92219 & 1.38444 & 14.76766 & 20.48234 & 12.731 & 24 & .000 \\
\hline
\end{tabular}

Berdasarkan uji $\mathrm{t}$ di atas dari kedua sampel yang diteliti yakni hasil angket kemandirian belajar mahasiswa pada kelas eksperimen dan kontrol setelah diterapkan pembelajaran dieperoleh rata - rata di kelas eksperimen sebesar 115.36 dan rata - rata pada kelas kontrol sebesar 110.88. Karena hasil nilai rata - rata tingkat kemandirian belajar mahasiswa setelah diterapkan pembelajaran pada kelas eksperimen lebih besar darpada kelas kontrol artinya secara deskrptif terdapat perbedaan rata - rata kemandirian belajar mahasiswa kelas eksperimen dan kontrol.

Selanjutnya pada uji t kemampuan berpikir kritis mahasiswa diperoleh nilai rata-rata yaitu sebesar 76.12 untuk kelas eksperimen dan 58.50 untuk kelas kontrol sehingga terjadi peningkatan 
sebesar 17.62 atau sekitar 12,04\%. Berdasarkan penjelasan data di atas diketahui hasil postes kelas eksperimen lebih tinggi apabila disejajarkan dengan kelas kontrol. Artinya kelas yang mendapatkan perlakuan Blended Learning tingkat keampuan berpikir kritis lebih baik darpada kelas kontrol. Hasil penelitian membuktikan bahwa dengan diterapkannya model pembelajaran Blended Learning, kemampuan berpikir kritis mahasiswa meningkat.

Dalam penelitian ini nilai postes dapat dijadikan sebagai pengukuran tingkat kemampuan berpikir kritis mahasiswa. Pada kelas eksperimen, mahasiswa dapat melakukan kegiatan tanya jawab secara virtual melalui google meeting mengenai materi ekonomi yang sulit dimengerti. Pembelajaran. Berdasarkan uji hipotesis yang telah dilakukan dapat dinyatakan bahwasanya penerapan Model pembelajaran Blended Learning berpengaruh pada peningkatan kemampuan berpikir kritis mahasiswa.

Kemudian berdasarkan uji pared sampel t test diketahui nilai sig. (2-tailed) adalah $0.00<0.05$ menunjukkan adanya perbedaan rata-rata kemandirian belajar kelas kontrol dan kelas eksperimen, Artinya ditemukan adanya selisih rata-rata tingkat kemandirian belajar mahasiswa dan kemampuan berpikir kritis mahasiswa. Hasil penelitian menjelaskan bahwa penerapan model pembelajaran Blended Learning di kelas eksperimen dapat meningkatan kemandirian belajar mahasiswa. Pada kelas eksperimen, mahasiswa lebih aktif untuk mengikuti proses pembelajaran yang dilakukan dengan diterapkannya model pembelajaran Blended Learning. Hal ini disebabkan mereka merasa bahwa secara mandiri dan terarah mereka dapat memahami materi kuliah, karena kegiatan perkuliahan tidak hanya melalui daring melalui google meet saja namun dapat berdiskusi di google classroom dengan arahan dan bimbingan dosen yang jelas dan terarah, proses pembelajaran juga menjadi dua arah.

Berbeda dengan kelas kontrol yang hanya menggunakan google meet untuk melaksanakan perkulihan. Dengan adanya keterbatasan kondisi saaat ini, maka penerapan model pembelajaran yang tepat sangat diperlukan oleh mahasiswa guna dapat belajar secara maksimal dan target yang diinginkan tercapai. Hal ini Senada dengan sebuah hasil penelitian yaitu penggunaan model pembelajaran yang sesuai dapat menumbuhkan rasa cinta dan ketertarikan siswa pada pelajaran sehingga dapat memperoleh nilai yang maksimmal (Aunurrahman, 2013). Sehingga dapat disimpulkan bahwa model pembelajaran Blended Learning efektif digunakan sebagai salah satu solusi model pembelajaran yang dapat digunakan di masa pandemic covid-19 maupun new normal.

Didukung oleh penelitian yang menyatakan bahwasanya Blended Learning berpengaruh terhadap kemandirian belajar yang ditunjukkan dengan skor kemandirian belajar kelas eksperimen lebih unggul dari kelas kontrol (Uz \& Uzun, 2018). Selanjutnya hasil penelitian yang menyatakan "The results showed that there was a significant influence using Blended Learning to the students' critical thinking skills. Thus it is recommended that lecturers use the Blended Learning model"(Simbolon et al., 2019) dan juga hasil penelitian yang menyatakan peningkatan kemampuan mahasiswa untuk berpikir kritis antara sebelum implementasi Strategi Blended Learning yaitu sebesar 
19,3\%, dan setelah siklus terakhir pengimplementasian Strategi Blended Learning adalah sebesar $88,6 \%$ (Sari, 2013)

\section{KESIMPULAN}

Berdasarkan deskripsi hasil yang telah dipaparkan di atas, dapat disimpulkan bahwa: (1) Keterlaksanaan pembelajaran yang telah diamati oleh obsever menunjukkan hasil yang menyatakan bahwasanya pembelajaran yang dilakukan menggunakan model pembeajaran Blended Learning dapat terlaksana dengan baik dengan nilai persentase senilai 94.12\%; (2) Penerapan model pembelajaran Blended Learning pada mata kuliah statistik yang apabila ditinjau dari respon mahasiswa yaitu sebesar $89.50 \%$ dan dikategorikan baik sehinggan dikatakan efektif untuk diterapakan di masa pandemi Covid-19 dan new normal; (3) Terdapat perbedaan tingkat kemandirian belajar yang dibuktikan pada perolehan rata-rata maupun skor total kemandirian belajar kelas eksperimen yang lebh unggul yaitu sebesar 2.88 dan 2.77 pada kelas kontrol. Artinya perlakuan model pembelajaran Blended Learning pada kelas eksperimen terbukti dapat meningkatkan kemandirian belajar mahasiswa; (4) Terdapat perbedaan kempuan berpikir kritis antara mahasiswa yang diajar menggunakan model pembelajaran Blended Learning dengan pembelajaran konvesional. Dengan nilai Sig. (2-tailed) 0,00 tidak lebih dari taraf signifikasi 0,05 yaitu $0,00<0,05$, bermakna bahwa terlihat adanya perbedaan nilai postes diantara kedua kelas. Dapat ditunjukkan berdasarkan nilai rata-rata yaitu sebesar 76.12 untuk kelas eksperimen dan 58.50 untuk kelas kontrol. Terdapat peningkatan sebesar 17.62 atau sekitar 12,04\%.

\section{UCAPAN TERIMA KASIH}

Penulis mengucapkan terimakasih kepada Kemendikbud Ristek yang telah membiayai penelitian. Rektor Universitas Pembinaan Masyarakat (UPMI) Medan beserta staff dan jajarannya yang telah membantu penulis dalam melaksanakan penelitian ini.

\section{REFERENSI}

Atsani, Lalu Gede Muhammad Zainuddin, KH. (2020). Transformasi Media Pembelajaran Pada Masa Pandemi Covid-19. Jurnal Teknologi Pendidikan, 22(1), 65-70. http://journal.unj.ac.id/unj/index.php/jtp

Aunurrahman. (2013). Belajar dan Pembelajaran. Alfabeta.

Hendra, I. (2014). Pemanfaatan Teknologi dalam Kegiatan Belajar Mengajar Untuk Perluasan Akses Pendidikan. Kemendikbud Pusat Pengembangan Pendidikan Anak Usia Dini Non Formal Dan Informal Regional II, 1-5.

Hendriana, H., \& Soemarmo, U. (2014). Penilaian pembelajaran matematika. Refika.

Husamah. (2014). Pembelajaran Blended Learning. In Economist (Vol. 366, Issue 8308).

Kenney, J., \& Newcombe, E. (2011). Adopting a Blended Learning approach: Challenges 
encountered and lessons learned in an action research study. Journal of Asynchronous Learning Network, 15(1), 45-57. https://doi.org/10.24059/olj.v15i1.182

Lumbantoruan, E. P., \& Hidayat, P. (2013). Model Pembelajaran Blended Learning dengan Media Blog. 2002, 14-27.

Mahmudah, U. (2020). Metode Statistika: Step By Step. https://www.researchgate.net/publication/341778110

Ningsih, Y. L., Misdalina, M., \& Marhamah, M. (2017). Peningkatan Hasil Belajar dan Kemandirian Belajar Metode Statistika Melalui Pembelajaran Blended Learning. Al-Jabar: Jurnal Pendidikan Matematika, 8(2), 155. https://doi.org/10.24042/ajpm.v8i2.1633

Prabawati, M. . (2011). Pengaruh penggunaan Pembelajaran Kontekstual dengan Teknik SQ3R Terhadap Peningkatan Kemampuan Pemahaman dan Berpikir kritis Matematis Siswa SMA [Universitas Pendidikan Indonesia]. In Records Management Journal (Vol. 1, Issue 2). http://citeseerx.ist.psu.edu/viewdoc/download?doi=10.1.1.88.5042\&rep=rep1\&type=pdf\%0Ahtt ps://www.ideals.illinois.edu/handle/2142/73673\%0Ahttp://www.scopus.com/inward/record.url? eid=2-s2.0-33646678859\&partnerID=40\&md5=3ee39b50a5df02627b70c1bdac4a60ba\%0Ahtt

Riduwan. (2011). Skala Pengkuran Variabel-variabel Penelitian. Alfabeta.

Sari, A. R. (2013). Strategi Blended Learning Untuk Peningkatan Kemandirian Belajar Dan Kemampuan Critical Thinking Mahasiswa Di Era Digital. Jurnal Pendidikan Akuntansi Indonesia, 11(2), 32-43. https://doi.org/10.21831/jpai.v11i2.1689

Simbolon, N., Simanjuntak, E., \& Perangin- angin, L. (2019). Blended Learning Oriented Kkni Towards Students Critical Thinking. Elementary School Journal, 9(3), 210-218. https://doi.org/10.24114/esjpgsd.v9i3.16356

Sumarmo, U. (2002). Kemandirian Belajar: Apa, Mengapa, dan Bagaimana dikembangkan pada Peserta Didik [Learning Independence: What, Why, and How it is developed into the students]. Academia.Edu, 1983, 1-9.

Uz, R., \& Uzun, A. (2018). The influence of Blended Learning environment on self-regulated and self-directed learning skills of learners. European Journal of Educational Research, 7(4), 877886. https://doi.org/10.12973/eu-jer.7.4.877

Wahyuni, R. (2013). Peningkatan Kemampuan Pemecahan Masalah Matematis dan Kemandirian Belajar Siswa Melalui Penerapan Model Pembelajaran Kooperatif Tipe Think Pair Share(TPS), Tesis.Unimed.

Zumbrunn, S. (2011). Encourage self regulated learning in the classroom. Journal Virginia Commonwealth University, 278-299. http://scholarscompass.vcu.edu/merc_pubs/18. 